\title{
Curcumin derivative C212 inhibits Hsp90 and eliminates both growing and quiescent leukemia cells in deep dormancy
}

Bi Liu ${ }^{1,2+}$, Yunzhu Shen ${ }^{1,3+}$, Huafang Huang ${ }^{1}$, Kimiko Della Croce², Min Wu', Yingjuan Fan'1, Yang Liu*, Jianhua $\mathrm{Xu}^{1 *}$ and Guang $\mathrm{YaO}^{2,4^{*}}$ (D)

\begin{abstract}
Background: Relapsed leukemia following initial therapeutic response and remission is difficult to treat and causes high patient mortality. Leukemia relapse is due to residual quiescent leukemia cells that escape conventional therapies and later reemerge. Eliminating not only growing but quiescent leukemia cells is critical to effectively treating leukemia and preventing its recurrence. Such dual targeting therapeutic agents, however, are lacking in the clinic. To start tackling this problem, encouraged by the promising anticancer effects of a set of curcumin derivatives in our earlier studies, we examined in this work the effects of a 4-arylmethyl curcumin derivative (C212) in eliminating both growing and quiescent leukemia cells.

Methods: We analyzed the effects of C212 on the growth and viability of growing and quiescent leukemia cells using MTS, apoptosis, cell cycle and cell tracking assays. The effects of C212 on the quiescence depth of leukemia cells were measured using EdU incorporation assay upon growth stimulation. The mechanisms of C212-induced apoptosis and deep dormancy, particularly associated with its inhibition of Hsp90 activity, were studied using molecular docking, protein aggregation assay, and Western blot of client proteins.

Results: C212, on the one hand, inhibits growing leukemia cells at a higher efficacy than curcumin by inducing apoptosis and G2/M accumulation; it, on the other hand, eliminates quiescent leukemia cells that are resistant to conventional treatments. Furthermore, C212 drives leukemia cells into and kills them at deep quiescence. Lastly, we show that C212 induces apoptosis and drives cells into deep dormancy at least partially by binding to and inhibiting Hsp90, leading to client protein degradation and protein aggregation.

Conclusion: C212 effectively eliminates both growing and quiescent leukemia cells by inhibiting Hsp90. The property of C212 to kill quiescent leukemia cells in deep dormancy avoids the risk associated with awaking therapyresistant subpopulation of quiescent leukemia cells during treatments, which may lead to the development of novel therapies against leukemia relapse.
\end{abstract}

Keywords: Leukemia, Relapse, Quiescence, Dormancy, Curcumin derivative, Hsp90, Apoptosis, Protein aggregation

\footnotetext{
* Correspondence: liuyang@fjmu.edu.cn; xjh@fjmu.edu.cn; guangyao@arizona.edu

${ }^{\dagger}$ Bi Liu and Yunzhu Shen contributed equally to this work.

${ }^{1}$ School of Pharmacy, Fujian Provincial Key Laboratory of Natural Medicine Pharmacology, Fujian Medical University, Fuzhou 350122, China

${ }^{2}$ Department of Molecular and Cellular Biology, University of Arizona, Tucson, AZ 85721, USA

Full list of author information is available at the end of the article
}

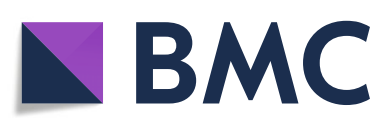

( The Author(s). 2020 Open Access This article is licensed under a Creative Commons Attribution 4.0 International License, which permits use, sharing, adaptation, distribution and reproduction in any medium or format, as long as you give appropriate credit to the original author(s) and the source, provide a link to the Creative Commons licence, and indicate if changes were made. The images or other third party material in this article are included in the article's Creative Commons licence, unless indicated otherwise in a credit line to the material. If material is not included in the article's Creative Commons licence and your intended use is not permitted by statutory regulation or exceeds the permitted use, you will need to obtain permission directly from the copyright holder. To view a copy of this licence, visit http://creativecommons.org/licenses/by/4.0/. The Creative Commons Public Domain Dedication waiver (http://creativecommons.org/publicdomain/zero/1.0/) applies to the data made available in this article, unless otherwise stated in a credit line to the data. 


\section{Background}

Conventional chemotherapy drugs target fast-growing cells and induce cell death or cell cycle arrest, typically by damaging DNA or microtubules or inhibiting enzymes required for cell proliferation [1-3]. These drugs, e.g., doxorubicin, paclitaxel and topotecan, are ineffective against slow-growing or quiescent cancer cells that do not undergo active DNA replication and cell division $[4,5]$. Accordingly, quiescent cancer cells, including but not limited to cancer stem cells, escape conventional chemotherapies; they often reemerge after a period of dormancy, causing cancer relapse and metastasis that are exceedingly difficult to treat and lead to high patient mortality [6-8].

The ability to eliminate both growing and quiescent cancer cells is critical to treating cancer and preventing cancer recurrence $[9,10]$. In contrast to a long list of chemotherapy drugs against growing cancer cells, effective agents eliminating quiescent cancer cells are lacking in the clinic $[5,10]$. How to eradicate quiescent slowgrowing cancer cells has only begun to be explored, primarily from metabolic and epigenetic angles [11-14]. Recently, we identified two natural compounds, ergosterol peroxide and ganodermanondiol, from the medical mushroom Ganoderma lucidum [15]. We showed that these two compounds eliminated quiescent slow-cycling cells by pushing cells to shallow quiescence and exposing them to cytotoxic effects [15]. Awaking quiescent cancer cells to kill presents a strategy to prevent cancer recurrence [16]. However, if some of these quiescent cancer cells develop and acquire therapy resistance during dormancy $[4,10]$, waking them can be risky.

Can we identify therapeutic agents that eliminate both growing and quiescent cancer cells, without the risk of awakening the latter from dormancy during the treatment? In this work, we studied such potential effects of a curcumin (diferuloylmethane) derivative. Curcumin is the primary natural polyphenol found in the rhizome of Curcuma longa (turmeric) and others Curcuma spp. [17]; it exhibits pharmacological effects on a wide range of human diseases $[17,18]$. Particularly, it inhibits cancer growth in the reproductive, digestive, urinary, pulmonary, nervous, skeletal, skin, lymphatic, and immune systems, attributing to its immunomodulatory, antiinflammatory, antioxidant, pro-apoptotic, and antiangiogenic properties [19-24]. At the molecular level, curcumin interacts with multiple cellular pathways: it inhibits NF- $\mathrm{KB}, \mathrm{Akt} / \mathrm{PI} 3 \mathrm{~K}$, and MAPK pathways and enhances p53 activity, to name a few $[20,21]$. Recent work [25, 26], including ours [27], showed that curcumin suppresses tumor growth by inhibiting the molecular chaperone function of heat shock protein 90 (Hsp90). Hsp90 chaperone stabilizes a large group of client proteins, including those essential for tumor growth and survival (e.g., Her2, BCR-ABL, and Akt) [28-30]. Accordingly, small molecular drugs that inhibit Hsp90, causing the degradation of Hsp90 client proteins, have exhibited anticancer effects [31-33]. Inhibiting Hsp90 also increases protein aggregation that in turn induces deep quiescence in both bacteria and neural stem cells $[34,35]$.

Following the anticancer effect of curcumin, we [3640] and others [41-43] have designed and synthesized curcumin derivatives to address the low bioavailability of curcumin and further improve its anticancer efficacy. Some of these curcumin derivatives (e.g., C086 and C1206) in our earlier studies preserved the Hsp90 inhibition function of curcumin and have shown promising effects against chronic myeloid leukemia (CML) cells $[37,38]$ and colon cancer cells and xenograft tumors [36]. Here we report that a novel curcumin derivative, C212, exhibits a dual function in eliminating both growing and quiescent leukemia cells; it eliminates quiescent leukemia cells in deep dormancy without waking them up, presenting an attractive approach to prevent leukemia recurrence.

\section{Materials and methods \\ Reagents}

C212 was synthesized in our laboratory as described previously [39]. Paclitaxel was purchased from LC Laboratories (P-9600), Topotecan from Sigma (T2705), Doxorubicin from Cayman (15007), and 17-AAG from APExBIO (A405410). The cloning, expression, and purification of the histidine (His)-targeted yeast full-length Hsp90 (1-732, $90 \mathrm{kDa})$, N-terminus of Hsp90 (N-Hsp90, $1-236,25 \mathrm{kDa}$ ), middle region of $\mathrm{Hsp} 90$ (M-Hsp90, 272-617, $40 \mathrm{kDa}$ ), and C-terminus of Hsp90 (C-Hsp90, $629-732,15 \mathrm{kDa})$ were performed as described in previous work [44].

\section{Cell culture and quiescence induction}

K562, HL60, SW620, and MCF-7 cells were cultured in RPMI-1640 medium (Corning, 10040CV) containing 10\% bovine growth serum (BGS; Hyclone, SH30541.03). HCT116 cells were cultured in McCoy's 5A medium (Corning, 1005CV) containing 10\% BGS. HT-29, SGC7901, and HepG2 cells were cultured in Dulbecco's Modified Eagle Medium (DMEM; Hyclone, SH30022.01) containing $10 \%$ BGS. To induce quiescent or slowgrowing leukemia cells, normal growing cells were spun down, washed once, and plated (in 12-well plates) in the starvation medium: HL60, serum-free DMEM (Corning, 15-013-CV, without glutamine), for $12 \mathrm{~h}$; K562, serumand amino acid-free Earle's balanced salt solution EBSS (Gibco, 24,010,043), for $36 \mathrm{~h}$. To induce quiescence exit and cell cycle re-entry, starved leukemia cells were switched to serum stimulation medium: HL60, DMEM 
(with glutamine) containing 2.5\% BGS; K562, EBSS containing $2.5 \%$ BGS. To induce quiescent or slow-growing colon cancer cells, normal growing HCT116 and SW620 cells were seeded in 12-well plates and incubated overnight in culture media (see above), then starved in serum- and amino acid-free EBSS for 12 and $24 \mathrm{~h}$, respectively.

\section{Cell growth/viability MTS assay}

Cells were seeded in 96-well plates and cultured in $100 \mu \mathrm{l}$ medium with $\mathrm{C} 212$ or other drugs at the indicated doses and durations in figure legend (Figs.1, 4, and S4-5); $20 \mu \mathrm{l}$ CellTiter stock solution (Promega, G3510) was added into each well, followed by a 3-h incubation at $37^{\circ} \mathrm{C}$. The absorbance of each well was measured at $490 \mathrm{~nm}$, with the absorbance of wells containing medium and CellTiter only set as the background control $\left(\mathrm{A}_{\text {background }}\right)$ and the absorbance of wells containing cells treated with vehicle set as the vehicle control
$\left(\mathrm{A}_{\text {control }}\right)$. Cell growth $/$ viability $=\left(\mathrm{A}_{\text {treatment }}-\mathrm{A}_{\text {background }}\right) /$ $\left(A_{\text {control }}-A_{\text {background }}\right) * 100 \%$.

\section{Apoptosis assays}

The annexin V-FITC/PI staining assay was carried out according to the manufacturer's protocol (BD, 556547). Briefly, leukemia cells were spun down, washed once in DPBS, resuspended in $100 \mu \mathrm{L}$ Annexin-V/PI staining buffer, and kept in the dark for $15 \mathrm{~min}$ at $37^{\circ} \mathrm{C}$; cells were then washed once with $200 \mu \mathrm{l}$ wash buffer provided by the kit, followed by FITC-PI fluorescence intensity measurement using flow cytometry. To assess mitochondrial membrane potential (MMP) depolarization during early apoptosis, leukemia cells were spun down, resuspended in $300 \mu \mathrm{L}$ JC-1 staining solution (KeyGEN Biotech, KGA603), and kept in the dark at room temperature for $10 \mathrm{~min}$; cells were washed twice with the wash buffer provided by the kit, followed by JC-1 fluorescence intensity measurement using flow cytometry. JC-1 is a cationic dye that accumulates in

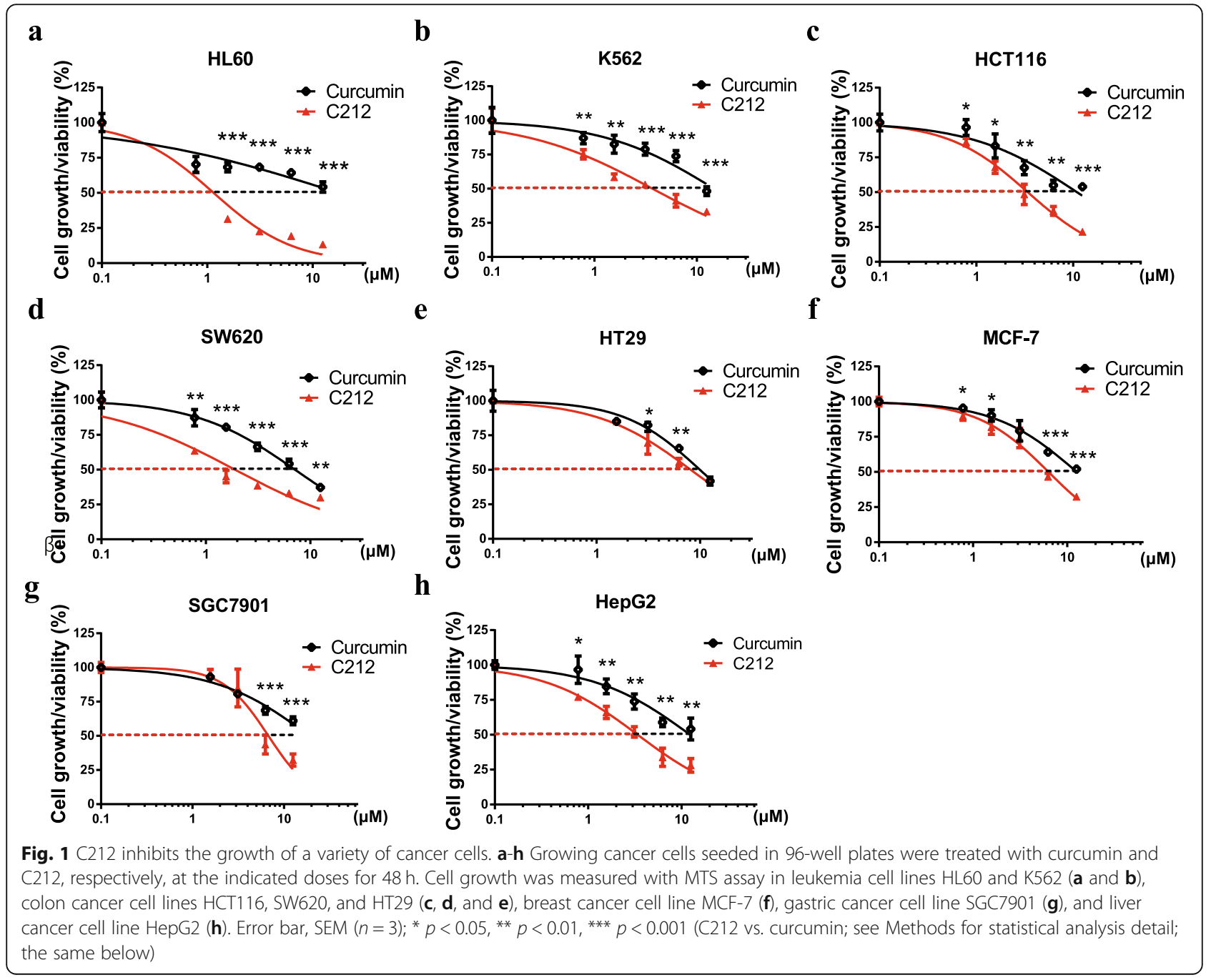


mitochondria and forms red fluorescent aggregates at high MMP; a decrease of JC-1 red fluorescence indicates MMP depolarization.

\section{Cell cycle and EdU incorporation assays}

To assess DNA content, leukemia cells were spun down and resuspended in $500 \mu \mathrm{l} 70 \%$ ethanol for overnight at $-20^{\circ} \mathrm{C}$; cells were then washed once with $300 \mu$ l cold DPBS, resuspended in $300 \mu \mathrm{l}$ DNA-staining solution containing propidium iodide (PI; Sigma, P4170) and RNase A (Sigma, R6513) at final concentrations of $50 \mu \mathrm{g} / \mathrm{ml}$ in DPBS, incubated in the dark for $30 \mathrm{~min}$ at $37^{\circ} \mathrm{C}$, followed by PI intensity measurement using flow cytometry. To assess EdU incorporation during DNA synthesis after cell cycle re-entry from quiescence, $2 \mu \mathrm{M}$ EdU was included in serum stimulation medium for 43 and $24 \mathrm{~h}$, respectively, for HL60 and K562 cells, followed by click-iT EdU assay according to the manufacturer's protocol (Life Technologies, C10418) [45]; EdU intensity was measured using flow cytometry.

\section{Live cell tracking staining}

To track cell division status, cells were stained with a cell tracking dye CFSE (Invitrogen, C1157) according to the manufacturer's protocol. Briefly, growing leukemia cells were washed once with DPBS and incubated with $500 \mu \mathrm{l} 1 \mathrm{x}$ CFSE in DPBS at $37^{\circ} \mathrm{C}$ for $20 \mathrm{~min}$. Cells were then washed once with culture medium, and returned to previous culture condition before the staining. Cells were harvested at indicated time points (Fig. 3a), and CFSE dye intensity was measured using flow cytometry.

\section{Western blot}

Whole-cell lysates were prepared with RIPA lysis buffer as described previously [37]. Approximately $40 \mathrm{mg}$ of protein lysate per sample was loaded and separated in 8-12\% SDS-PAGE gel and then transferred to PVDF membrane (Roche, 03010040001); membrane was blocked with $5 \%$ non-fat dry milk for $1 \mathrm{~h}$ and then incubated with primary antibodies at $4{ }^{\circ} \mathrm{C}$ overnight, followed by secondary antibody incubation for $2 \mathrm{~h}$ at room temperature and imaging. Primary antibody were purchased from Cell Signaling Technology (CST): Caspase 9 (9508S), Caspase 7 (9492S), Caspase 3 (9662S), PARP (9542 T), Cleaved-Caspase 9 (7237S), Cleaved-Caspase7 (8438S), Cleaved-Caspase 3 (9664S), Cleaved-PARP (5625S), Cytochrome C (Cyt,c, 4280S), Akt (4691S), pAKT (4060S), Raf 9422S), p-Raf (9421S), Mek (4694S), p-Mek (2338S), Erk (4695S), p-Erk (4377S), Cyclin B1 (4135S), Cdc2 (9116S), p-Cdc2 (4539S), $\beta$-actin (4970S), $\beta$-actin (MA1-140); secondary antibody goat anti-rabbit IgG-HRP was purchased from Santa Cruz Biotechnology (sc-7074). Western blot bands were quantified using
ImageJ with background noise removed using RollingBall correction.

\section{Hsp90-interaction analysis}

For the molecular docking analysis, chain A of the crystal structure of an Hsp90-Sba1 closed chaperone complex was extracted from Protein Data Bank (PDB, ID: 2CG9), from which structures of Hsp90 C- and Nterminus were derived [46]; the bindings between Hsp90 domains and curcumin/C212 were simulated using the Surflex-Dock program (SYBYL-X v1.3). For the quenching assay of intrinsic Hsp90 fluorescence, a C212 solution ( 0 to $50 \mu \mathrm{M}$ in $0.2 \%$ DMSO) was successively added into $2.0 \mathrm{~mL}$ Hsp90 solution (5.0 $\mu \mathrm{M}$ in PBS, $\mathrm{pH} 7.6)$; fluorescence intensity was recorded from 290 to $500 \mathrm{~nm}$ at 303 Kelvin using a Cary Eclipse spectrofluorometer (Varian/Agilent).

\section{Protein aggregation assay}

The accumulation of protein aggregates in the cell was assessed using the ProteoStat Aggresome detection kit (Enzo, ENZ-51035-K100) according to the manufacturer's protocol. Briefly, leukemia cells were spun down, fixed with $200 \mu \mathrm{l} 4 \%$ paraformaldehyde at room temperature for $20 \mathrm{~min}$, and permeabilized with $200 \mu \mathrm{l}$ assay buffer containing $0.5 \%$ Triton-X100 and $3 \mathrm{mM}$ EDTA in PBS on ice for $20 \mathrm{~min}$. ProteoStat staining solution was added to cell suspension at 1:5000 and incubated at room temperature for $30 \mathrm{~min}$, followed by ProteoStat fluorescence measurement using flow cytometry.

\section{Data and statistical analysis}

Cell growth/viability data were analyzed using Prism 6.0 (GraphPad), including curve fitting and IC50 calculation (using a non-linear regression fit, $\log$ (inhibitor) vs. normalized response - variable slope) as well as AUC calculation (using the trapezoidal rule). Flow cytometry data were analyzed using FlowJo v10.3 (BD). Statistical significance between two independent groups of measurements was determined using unpaired Student's $t$-test; 1-tailed tests were performed to assess C212-induced unilateral difference (increase or decrease) over control in all figures, except for Fig. S3-5 where 2-tailed tests were performed to assess the mixed change patterns observed.

\section{Results}

C212 inhibits the growth of a variety of cancer cells more effectively than curcumin

C212, (1E,6E)-4-(2-Chlorinebenzyl)-1,7-bis(3-pyridine)1,6-heptadiene-3,5-dione (Fig. S1A), was synthesized as one of several 4-arylmethyl curcumin analogues in our previous study [39]. Here we applied C212 and 
curcumin to a variety of cancer cell lines, including leukemia (AML HL60 and CML K562), colon cancer (HCT116, SW620, and HT29), breast cancer (MCF-7), gastric cancer (SGC7901), and liver cancer (HepG2). We found that both $\mathrm{C} 212$ and curcumin dose-dependently suppressed the growth of these cancer cell lines as shown in MTS assays (Fig. 1a-h). C212 further exhibited a stronger growth-inhibition effect than curcumin in each tested cancer cell line. Compared to curcumin, C212 exhibited (i) a lower IC50, the concentration required to inhibit cell growth by $50 \%$ (Fig. 1a-h; Table 1), and (ii) a smaller area under the curve (AUC in Fig. 1a$\mathrm{h}$; quantified in Table 1) that indicated a stronger cumulative growth-inhibition effect across the tested dose range.

Among the tested cell lines, leukemia cells as a group were the most sensitive to $\mathrm{C} 212$. In leukemia cells (HL60 and K562), the mean IC50 ratio (C212 vs. curcumin) was 0.16 as compared to $0.27-0.50$ in other cancer cell types (Table 1), and the mean AUC ratio (C212 vs. curcumin) was 0.75 as compared to $0.80-0.95$ in other cancer cell types (Table 1). These results indicated that leukemia cells underwent stronger growth-inhibition effects than other cancer cells did under C212 (compared to curcumin). We therefore focused on leukemia cells in subsequent C212 study.

C212 inhibits leukemia cell growth by inducing apoptosis and G2/M accumulation

We next tested the inhibitory effect of $\mathrm{C} 212$ on leukemia cell growth. It appeared to be twofold. First, C212 dosedependently induced apoptosis in HL60 and K562 cells. With an increasing C212 concentration, 1) the subpopulation of cells exhibiting the characteristic externalization of inner membrane phospholipids
(Annexin V-positive) and membrane compromise (PIpositive) increased monotonically in K562 (Fig. 2a, top) and HL60 cells (Fig. 2a, bottom); 2) the subpopulation of cells exhibiting the characteristic depolarized mitochondrial membrane potential (with reduced red fluorescence of JC-1 staining) increased monotonically in $\mathrm{K} 562$ (Fig. 2b, top) and HL60 cells (Fig. 2b, bottom); 3) the amounts of cleaved forms of PARP, caspase-9, caspase-7 and caspase-3, as well as the amount of cytochrome $\mathrm{C}$ (Cyt-C) in cell lysates that reflected primarily the level of released Cyt-C from mitochondria into cytoplasm, increased with $\mathrm{C} 212$ in K562 (Fig. 2c) and HL60 cells (Fig. 2d).

Second, C212 dose-dependently increased the proportion of cells accumulated at G2/M phase in both $\mathrm{K} 562$ and HL60 cells (Fig. S1 B and C). This result suggested in cells that survived apoptosis (Fig. 2), (a) G2/M progression was slowed down or arrested, which was consistent with the observed downregulations of $\mathrm{Cdc} 2$ and Cyclin B1 (G2/M "triggers") under C212 treatment (Fig. S1D), and/or (b) cells were more resistant to C212 cytotoxicity in G2/M than in other cell cycle phases. To test these potential mechanisms and examine how G2/M-accumulated cells behave under $\mathrm{C} 212$ over time, we first needed to identify and track C212-induced G2/Marrested cells, if any. To this end, we labeled cells with a cell trace dye CFSE after C212 treatment for $24 \mathrm{~h}(t 1$ point, Fig. 3a), we then followed cells under $\mathrm{C} 212$ for another $24 \mathrm{~h}$ ( $t 2$ point, Fig. 3a). At $t 1$ and $t 2$, a subset of cells was harvested, followed by propidium iodide (PI) DNA staining. Cells that were $\mathrm{G} 2 / \mathrm{M}$-arrested at $t 1$ would not divide and thus retain a $4 \mathrm{n}$ DNA content and the same CFSE intensity $(I)$ at $t 2, I_{t 2}=I_{t 1}$. In contrast, divided cells after $t 1$ had the CFSE dye split into two daughter cells, each with $I_{t 2}={ }^{1 / 2}{ }^{*} I_{t 1}$.

Table 1 IC50 values of C212 and curcumin in cancer cell lines (48-h treatment; Cur, curcumin)

\begin{tabular}{|c|c|c|c|c|c|c|c|c|c|}
\hline & & $\mathrm{HL}-60$ & K562 & HCT116 & SW620 & HT29 & MCF-7 & SGC7901 & HepG2 \\
\hline \multirow[t]{5}{*}{ Growth\% under C212 vs. Cur ( $p$-value) } & $0.8 \mu \mathrm{M}$ & $1.6 \mathrm{E}-01$ & 9.7E-03 & $3.3 \mathrm{E}-02$ & $9.4 \mathrm{E}-03$ & & $2.8 \mathrm{E}-02$ & & $3.5 \mathrm{E}-02$ \\
\hline & $1.6 \mu \mathrm{M}$ & $1.1 \mathrm{E}-03$ & 7.4E-03 & $3.5 \mathrm{E}-02$ & $5.6 \mathrm{E}-04$ & $4.8 \mathrm{E}-01$ & 4.7E-02 & 1.7E-01 & $4.9 \mathrm{E}-03$ \\
\hline & $3.2 \mu \mathrm{M}$ & $2.3 \mathrm{E}-07$ & 2.7E-03 & $1.2 \mathrm{E}-02$ & $3.3 \mathrm{E}-04$ & $6.0 \mathrm{E}-02$ & 2.2E-01 & $3.2 \mathrm{E}-01$ & $3.2 \mathrm{E}-03$ \\
\hline & $6.3 \mu \mathrm{M}$ & 7.0E-05 & 4.3E-04 & $1.5 \mathrm{E}-03$ & $8.1 \mathrm{E}-04$ & 4.6E-03 & 4.0E-04 & $1.3 \mathrm{E}-03$ & $5.4 \mathrm{E}-03$ \\
\hline & $12.5 \mu \mathrm{M}$ & $1.2 \mathrm{E}-03$ & 7.1E-03 & $3.6 \mathrm{E}-05$ & $9.5 \mathrm{E}-03$ & 4.6E-01 & $1.3 \mathrm{E}-04$ & 7.3E-04 & $6.2 \mathrm{E}-03$ \\
\hline \multirow[t]{3}{*}{ IC $50(\mu \mathrm{M})$} & C212 & 1.2 & 3.7 & 3.4 & 1.9 & 8.2 & 6.3 & 6.7 & 3.4 \\
\hline & Cur & 17.6 & 14.8 & 11.0 & 7.1 & 10.0 & 12.6 & 18.9 & 12.3 \\
\hline & C212/Cur & 0.07 & 0.25 & 0.31 & 0.27 & 0.82 & 0.50 & 0.36 & 0.27 \\
\hline Mean (IC50 C212/Cur) & & \multicolumn{2}{|c|}{0.16} & & 0.47 & & 0.50 & 0.36 & 0.27 \\
\hline \multirow[t]{3}{*}{$A \cup C$} & C212 & 108.1 & 140.4 & 145.2 & 122.1 & 173.5 & 164.0 & 174.7 & 140.5 \\
\hline & Cur & 155.5 & 174.6 & 173.2 & 162.9 & 180.0 & 179.7 & 183.4 & 175.9 \\
\hline & C212/Cur & 0.70 & 0.80 & 0.84 & 0.75 & 0.96 & 0.91 & 0.95 & 0.80 \\
\hline Mean (AUC C212/Cur) & & \multicolumn{2}{|c|}{0.75} & & 0.85 & & 0.91 & 0.95 & 0.80 \\
\hline
\end{tabular}




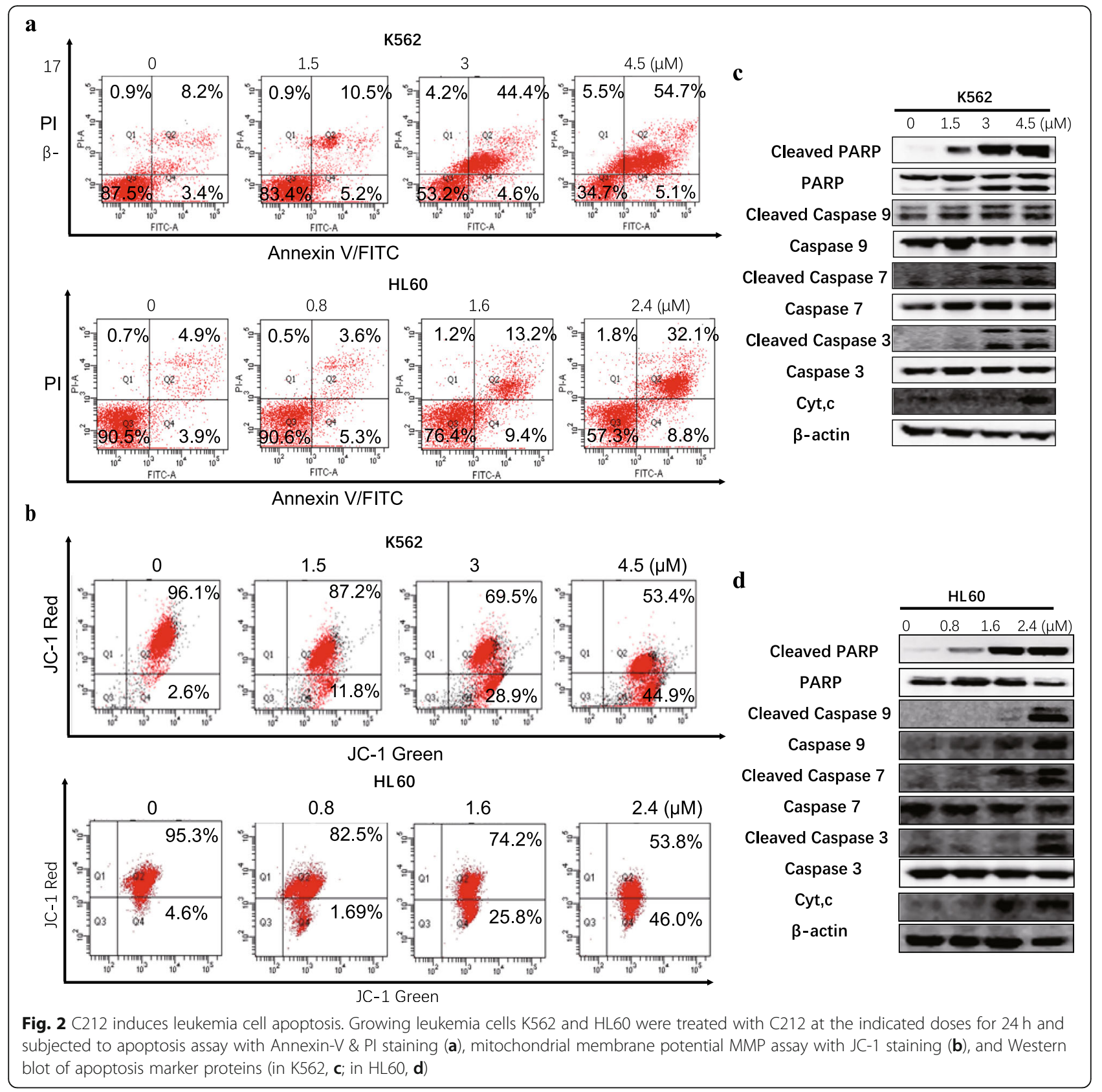

In $\mathrm{K} 562$ cells, when treated with $\mathrm{C} 212$ at the lower dose range $(0-3 \mu \mathrm{M})$, most cells were not arrested but divided: at $t 1$, cells were to the right of the black dash line $\left(I_{t 1}\right)$; at $t 2$, they shifted to the right of the red dash line $\left(I_{t 2}\right)$, with $I_{t 2}=1 / 2 * I_{t 1}$ (green arrows pointed, an example at $3 \mu \mathrm{M}$; Fig. 3b). In contrast, with $\mathrm{C} 212$ at the higher dose range ( 4.5 and $6 \mu \mathrm{M})$, most $\mathrm{K} 562$ cells were arrested after $t 1$ and remained to the right of the black dash line at $t 2$ (orange arrow pointed, an example at $4.5 \mu \mathrm{M}$; Fig. 3b). Furthermore, the G2/M\% in K562 cells increased significantly at high $\mathrm{C} 212$ doses over control (at both $t 1$ and $t 2$, Fig. $3 \mathrm{~d}$ ) and with time ( $t 2$ vs. $t 1$,
Fig. 3d), indicating a C212-induced $\mathrm{G} 2 / \mathrm{M}$ arrest. In comparison, most HL60 cells did not arrest their cell cycle, but divided at tested C212 doses and shifted to the right of red dash line by $t 2$ (Fig. 3c). Consistently, the G2/M\% in HL60 cells increased relatively modestly with increasing C212 doses (at both $t 1$ and $t 2$, Fig. 3e) and did not increase over time ( $t 2$ vs. $t 1$, Fig. 3e), suggesting a partial slowdown but not arrest at $G 2 / \mathrm{M}$ in most HL60 cells.

Were G2/M-arrested cells more resistant to C212 cytotoxicity than non-arrested ones? The significant enrichment of C212-induced G2/M-arrested cells in K562 


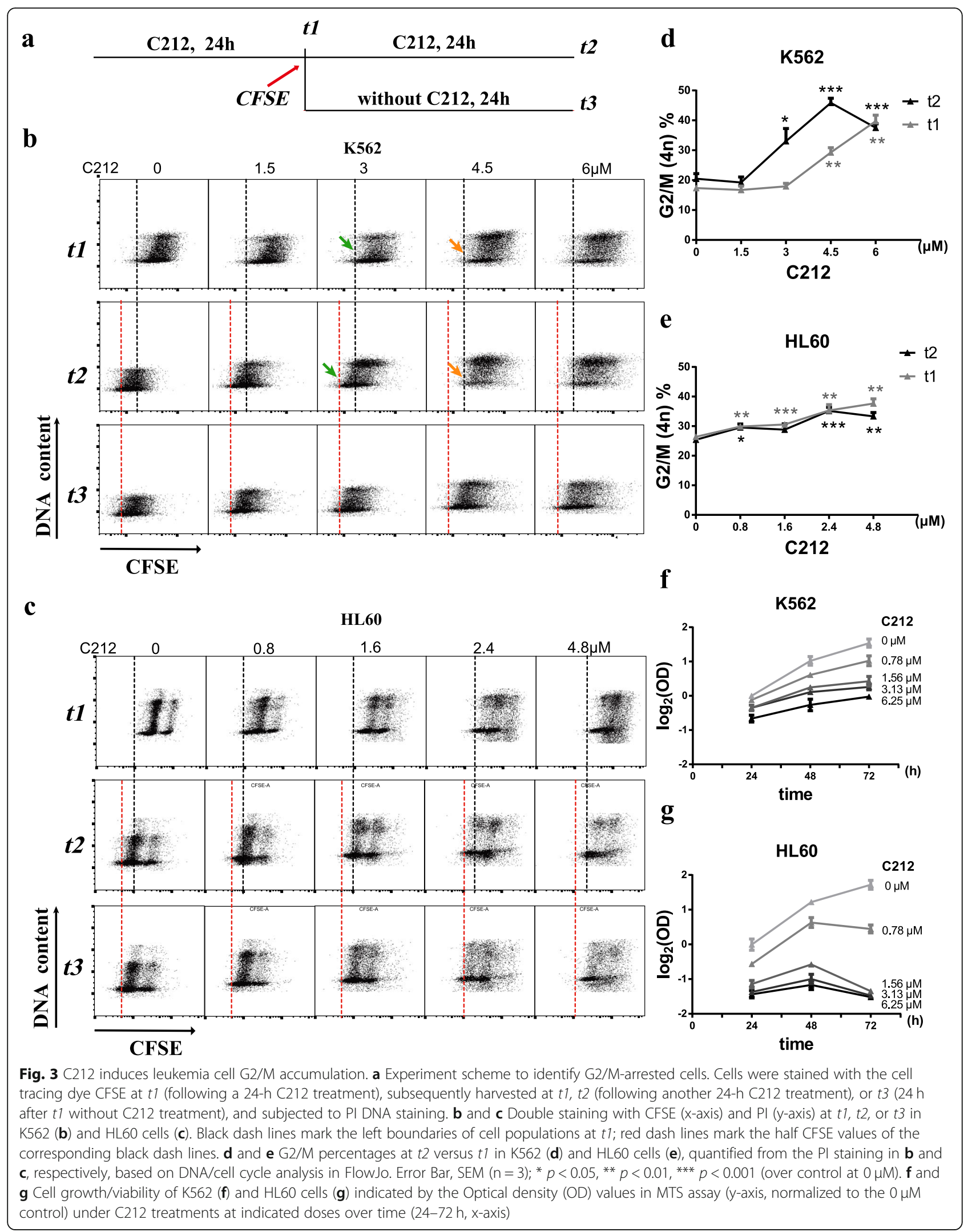


but not HL60 cells, correlated with the over 3-fold larger C212 IC50 in K562 than in HL60 (Table 1), was supportive of this notion. To test it further, we did a cell growth/ viability time-course analysis of K562 and HL60 cells under C212 treatment. In HL60 cells, the relative cell growth (in MTS assay) under C212 $(0.78-6.25 \mu \mathrm{M})$ between 24 and $48 \mathrm{~h}$ were lower than the vehicle control but still positive (Fig. 3g), while that between 48 and $72 \mathrm{~h}$ became negative (Fig. $3 \mathrm{~g}$ ), indicative of cell death surpassing growth. In comparison, the relative cell growth of $\mathrm{K} 562$ cells under C212 treatment remained positive (24 to 48 to 72 h; Fig. 3f). This discrepancy between K562 and HL60 cells further supported the notion that G2/M-arrested cells, enriched over time in K562 but not HL60 cells, were more resistant to $\mathrm{C} 212$ killing than non-arrested ones; they largely survived C212 treatment at least for $72 \mathrm{~h}$ (while cell death surpassed growth in HL60 cells after 48 h). Lastly, we note that the C212-induced G2/M-arrested cells were reversible - as seen in Fig. 3b, when C212 was removed, most cells arrested at $t 1$ divided and shifted from the right of the black dash line to the right of the red dash line after $24 \mathrm{~h}$ ( $t 3$, Fig. $3 \mathrm{~b})$.

\section{C212 eliminates quiescent leukemia cells in contrast to} chemotherapy drugs

Different from growing cells, quiescent cells are resistant to conventional chemotherapies that target cell proliferation machinery involving DNA replication and cell division. To test the cytotoxicity of $\mathrm{C} 212$ on quiescent leukemia cells, we first induced HL60 and K562 cells to quiescence or slow-growth by serum starvation: a $12-\mathrm{h}$ serum starvation reduced the percentage of actively proliferating (EdU + \%) HL60 cells from 98.3\% in growing condition to $8.1 \%$ (Fig. 4a); for K562 cells, which appeared to be less sensitive to serum growth signals than HL60, a 36-h serum starvation reduced EdU + \% from $98.8 \%$ in growing condition to $22.5 \%$ (Fig. $4 \mathrm{~b}$ ). As expected, chemotherapy drugs were inefficient in killing quiescent and slow-growing leukemia cells: the IC50 values of paclitaxel, topotecan, and doxorubicin in quiescent cells were several folds higher than the IC50 values in growing cells (HL60, Fig. 4e-g and Table 2; K562, Fig. 4i-k and Table 2). Similarly, Midostaurin [47], a targeted therapy drug against AML, was also inefficient in killing quiescent but growing leukemia cells, with the

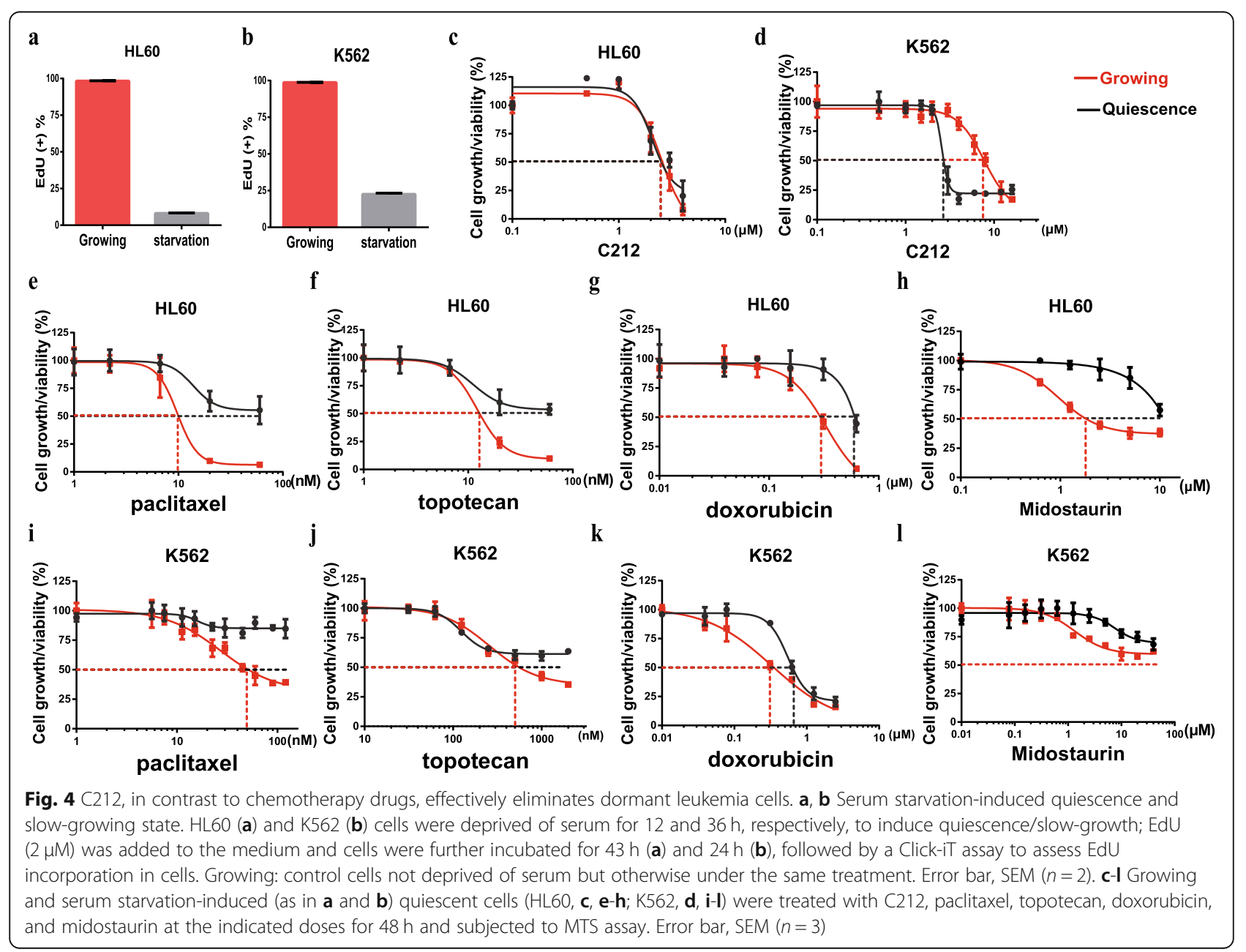


Table 2 IC50 values of chemotherapy and targeted therapy drugs vs. C212 in quiescent (Q) and growing (G) leukemia cells (48-h treatment)

\begin{tabular}{|c|c|c|c|c|c|c|c|c|c|c|c|c|}
\hline \multirow[t]{3}{*}{ Drugs } & \multicolumn{6}{|l|}{ HL60 } & \multicolumn{6}{|l|}{ K562 } \\
\hline & \multicolumn{3}{|l|}{ IC50 } & \multicolumn{3}{|l|}{$\mathrm{AUC}$} & \multicolumn{3}{|l|}{ IC50 } & \multicolumn{3}{|l|}{$\mathrm{AUC}$} \\
\hline & Q & G & $\mathrm{Q} / \mathrm{G}$ & Q & G & $\mathrm{Q} / \mathrm{G}$ & Q & G & $\mathrm{Q} / \mathrm{G}$ & Q & G & $\mathrm{Q} / \mathrm{G}$ \\
\hline Paclitaxel/nM & 62.2 & 10.8 & 5.76 & 148.2 & 103.8 & 1.43 & $>120$ & 58.5 & $>2.05$ & 191.8 & 162.7 & 1.18 \\
\hline Topotecan/nM & 57.8 & 13.3 & 4.35 & 142.8 & 112.9 & 1.27 & $>2000$ & 752.9 & $>2.66$ & 182.9 & 173.4 & 1.06 \\
\hline Doxorubicin/ $\mu \mathrm{M}$ & 0.6 & 0.3 & 2.00 & 162.5 & 139.3 & 1.17 & 0.7 & 0.4 & 1.75 & 182.0 & 149.5 & 1.22 \\
\hline Midostaurin/ $/ \mathrm{M}$ & 12.1 & 2.9 & 4.17 & 185.3 & 133.2 & 1.39 & & & & 324.5 & 300.4 & 1.08 \\
\hline $\mathrm{C} 212 / \mu \mathrm{M}$ & 2.3 & 2.3 & 1.00 & 128.7 & 124.3 & 1.04 & 2.8 & 7.7 & 0.36 & 154.3 & 178.3 & 0.87 \\
\hline
\end{tabular}

dose required to kill the same percentage of quiescent cells several fold higher than that of growing cells in both AML HL60 (Fig. 4h) and CML K562 (Fig. 4l) cells. By contrast, C212 exhibited the same IC50 $(2.3 \mu \mathrm{M})$ in both quiescent and growing HL60 cells (Fig. 4c). Furthermore, in K562 cells, the IC50 of C212 in quiescent cells $(2.8 \mu \mathrm{M})$ was only $36 \%$ of that in growing ones $(7.7 \mu \mathrm{M})$, indicating noticeably stronger cytotoxicity in quiescent than growing condition (Fig. 4d). Consistently, C212 exhibited a smaller AUC ratio (quiescence vs. growing) in both HL60 and K562 cells compared to paclitaxel, topotecan, doxorubicin, and midostaurin (Fig. 4c-d vs. e-l; Table 2), indicating stronger cumulative cytotoxicity of $\mathrm{C} 212$ against quiescent leukemia cells. We note our data also suggested that quiescent K562 cells (induced by serum starvation) differ from G2/M-arrested counterparts (induced at high C212 doses, Fig. 3b) - at these C212 doses (4.5 or $6 \mu \mathrm{M})$, the vast majority of quiescent $\mathrm{K} 562$ cells died, while most growing cells survived (Fig. 4d), particularly the G2/M-arrested ones (Fig. 3d). Put together, we concluded that in contrast to conventional chemotherapy drugs, C212 preferentially kills quiescent leukemia cells.

C212 drives quiescent leukemia cells into deep dormancy It has been previously reported that arsenic trioxide (As2O3) and certain cytokines (IFN- $\alpha$, G-CSF) were able to sensitize quiescent leukemia cells to chemotherapy cytotoxicity by reducing quiescence depth and waking them up [9]. Correspondingly, we examined whether C212 altered cell quiescence depth. To measure quiescence depth, we first induced leukemia cells into quiescent or slow-growth by serum starvation (for $12 \mathrm{~h}$ in HL60 and for $36 \mathrm{~h}$ in K562, same as in Fig. 4a and b); we then stimulated cells with serum (2.5\%) and measured the percentages of cells that exited quiescence and reentered the cell cycle $\left(E d U_{+}\right)$: deeper quiescent cells would be harder to exit quiescence and thus have smaller EdU + \% than shallower cells. When C212 was included in the last segment of serum starvation and through the serum stimulation phase (indicated with a red dash line, Fig. 5a and b), the $E d U+\%$ upon serum stimulation decreased in a C212 dose-dependent manner in HL60 cells (Fig. 5a), from 50.5\% $(0 \mu \mathrm{M})$ to $13.3 \%$ $(1.5 \mu \mathrm{M}$, sublethal according to Fig. 4c); in K562 cells that are less sensitive to serum signals than HL60, the relatively high EdU + \% background in serum starvation condition decreased in a C212 dose-dependent manner, as well as the EdU + \% upon serum stimulation (Fig. 5b) which decreased from $33.5 \%(0 \mu \mathrm{M})$ to $8.3 \%(2 \mu \mathrm{M}$, sublethal according to Fig. 4d). These results indicated that C212 treatment at increasing sublethal doses drove leukemia cells into deeper quiescence, so that a smaller percentage of quiescent cells was able to exit quiescence and re-enter the cell cycle given the same serumstimulation condition (2.5\%).

We next examined whether the effect of C212 to drive leukemia cells into deeper quiescence was exerted before or during quiescence exit or both. Our previous studies showed that quiescence depth is determined by various cellular activities during serum starvation and stimulation (i.e., before and during quiescence exit, respectively) that affect the serum threshold to activate an Rb-E2F bistable gene switch $[45,48]$. When C212 was included in the last segment of serum starvation but not the serum stimulation phase, cell cycle re-entry was not affected in HL60 cells (EdU + \% upon serum stimulation showed no statistically significant difference with or without C212; Fig. 5c) and was also not affected in K562 cells until the high C212 dose $(2 \mu \mathrm{M}$, Fig. $5 \mathrm{~d})$. When $\mathrm{C} 212$ was included in the serum stimulation phase but not in the last segment of serum starvation, cell cycle reentry was affected significantly in both HL60 and K562 cells, and EdU + \% upon serum stimulation decreased in a C212 dose-dependent manner (Fig. 5e and $\mathrm{f}$ ). Put together, our data suggested that C212 drove leukemia cells into deep quiescence, and it exerted this quiescence-deepening effect primarily by increasing the serum threshold during quiescence exit. 


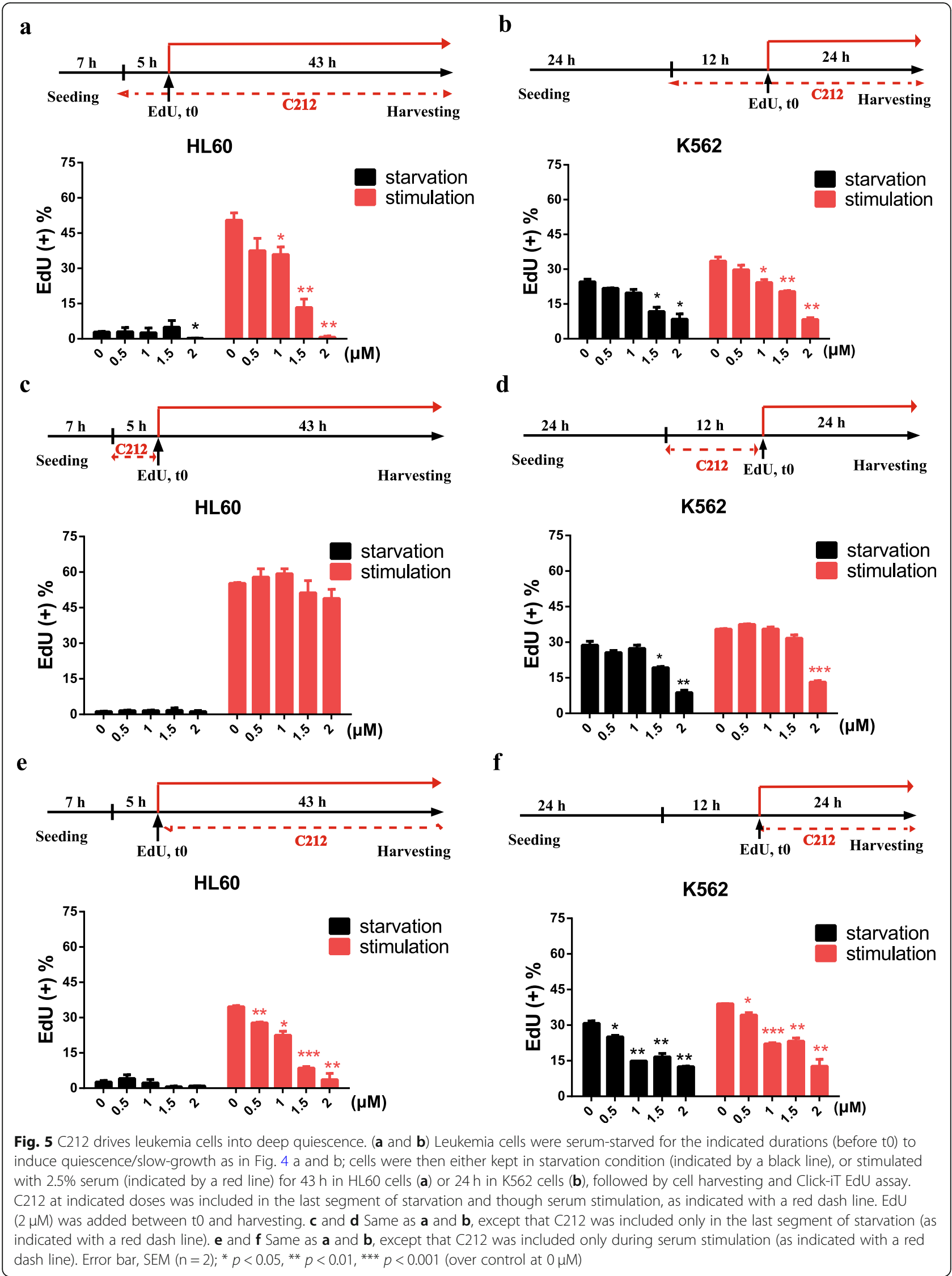




\section{C212 inhibits Hsp90 and induces client degradation and} protein aggregation in leukemia cells

As found in our previous work [27], curcumin binds to the $\alpha$-helix domain of $\mathrm{Hsp} 90$ at multiple residues (Fig. S2A) and inhibits the function of Hsp90 in folding and stabilizing client proteins-e.g., kinases that participate in cell proliferation. In our molecular docking analysis, C212 was also able to bind to the $\mathrm{C}$ - and $\mathrm{N}$-terminus as well as the middle (M) region of Hsp90 (Fig. S2A). When we carried out fluorescence quenching experiments with purified Hsp90 protein, we found that C212 dose-dependently quenched the intrinsic fluorescence of Hsp90 (excitation $/$ emission $=280 / 337 \mathrm{~nm}$ ), which was accompanied with blueshifts of $\lambda$ em curves (Fig. 6a). Specifically, the titration curves of $\mathrm{C} 212$ with the $\mathrm{N}$ terminus, M-region, and C-terminus of $\mathrm{Hsp} 90$ yielded estimated dissociation constants $\left(\mathrm{K}_{\mathrm{d}}\right)$ of $36.3,36.9$, and 15.3, respectively (Table 3 ), suggesting that $\mathrm{C} 212$ interacted with Hsp90.

Through binding to Hsp90, C212 was expected to behave like curcumin and interfere with the Hsp90 function in folding and stabilizing client proteins. Indeed, in both K562 and HL60 cells treated with C212, protein levels of Hsp90 clients Raf, Akt, Erk, and Mek, particularly in their phosphorylated forms, decreased in a C212 dose-dependent manner (Fig. 6b). The C212-induced decreases of Hsp90 client proteins were through proteasome-mediated degradation and could be blocked with a proteasome inhibitor MG-132 (Fig. S2B); they were not caused by decreases in Hsp90 protein level, which did not change or even increased modestly at nearly all tested conditions (Fig. S3 A and B, HL60; Fig. S3 $\mathrm{H}$ and I, K562).

We also found that $\mathrm{C} 212$ treatment induced the formation of protein aggregates. As seen in both HL60 (Fig. 6c, top) and K562 cells (Fig. 6c, bottom) induced to quiescence by serum starvation, the degree of protein aggregation (as measured by ProteoStat staining) increased in a C212 dose-dependent manner. This result was consistent with the notion that $\mathrm{C} 212$ interferes with Hsp90 function, which leads to the accumulation of misfolded proteins. Protein aggregates have been recently shown to drive deep cellular dormancy in both bacteria and neural stem cells [34, 35]. Since lysosomal activities are critical to partially clearing protein aggregates (as seen in quiescent neural stem cells [35]), we expected that blocking lysosomal activities would further increase protein aggregates and deepen quiescence in C212treated cells. Indeed, co-treating quiescent leukemia cells HL60 and K562 with C212 and a lysosome inhibitor chloroquine (CQ), compared to $\mathrm{C} 212$ treatment alone at all tested doses, further increased the degree of protein aggregation (as shown by higher ProteoStat fluorescence intensities, Fig. 6d) and deepened quiescence (as shown by the reduced EdU\% both under serum starvation (STA) and stimulation (STI), Fig. 6e).

\section{Discussion}

In this study, we found that C212, a 4-arylmethyl curcumin derivative demonstrates a dual anticancer effect against leukemia cells: it not only inhibits cell growth by inducing apoptosis and G2/M accumulation, but eliminates quiescent cells that are resistant to conventional chemotherapy drugs such as paclitaxel, doxorubicin, and topotecan, as well as the targeted therapy Midostaurin.

Quiescence is a reversible cellular dormancy state that can persist over prolonged periods. Leukemia relapse, despite initial therapeutic responses and remissions, is often due to the reemergence of residual quiescent cells, including leukemia stem cells [37, 49-52]. Therefore, effective therapies targeting and eliminating quiescent leukemic cells are critical to preventing leukemia relapse. In this regard, cytokines such as IFN- $\alpha$ and G-CSF, as well as arsenic trioxide As2O3, have been shown to wake up quiescent leukemia stem cells and sensitize them to chemotherapy [9]. However, some quiescent leukemia cells during long-term dormancy under stressful conditions can undergo genetic or epigenetic changes and further develop resistance to follow-up therapies [4, 10]; awakening these quiescent leukemia cells may therefore cause a risk.

C212 presents a likely safer strategy to prevent leukemia relapse by pushing quiescent leukemia cells into and killing them at deep dormancy, instead of waking them up. The effect of $\mathrm{C} 212$ to induce deep quiescence is at least partially due to its binding to Hsp90 and inhibiting Hsp90 function (Fig. 6a and b; Fig. S2A). Hsp90 is an evolutionarily conserved molecular chaperone that participates in stabilizing and activating more than 200 client proteins [30, 53]. Inhibiting Hsp90 function can lead to clients degradation (discussed further below) as well as the aggregation of misfolded proteins. Consistently, C212 dose-dependently induces protein aggregation (Fig. 6c) and drives quiescent leukemia cells into deep dormancy at sublethal doses by creating a higher serum threshold during quiescence exit (Fig. 5), a notion we summarized in Fig. 6 f.

Previously, we have found that by inhibiting Hsp90, curcumin and its derivatives induce the degradation of Hsp90 client proteins and correspondingly the growth arrest and apoptosis of leukemia cells [27, 37, 38]. These results were expected as many Hsp90 client proteins, such as kinases and transcription factors, are critical to cellular homeostasis and cell survival against stressful conditions [28-30, 54]. Similarly, C212 binds to and inhibits Hsp90, induces the degradation of Hsp90 client proteins (Fig. 6b), and induces apoptosis in K562 and HL60 leukemia cells (Fig. 2). 


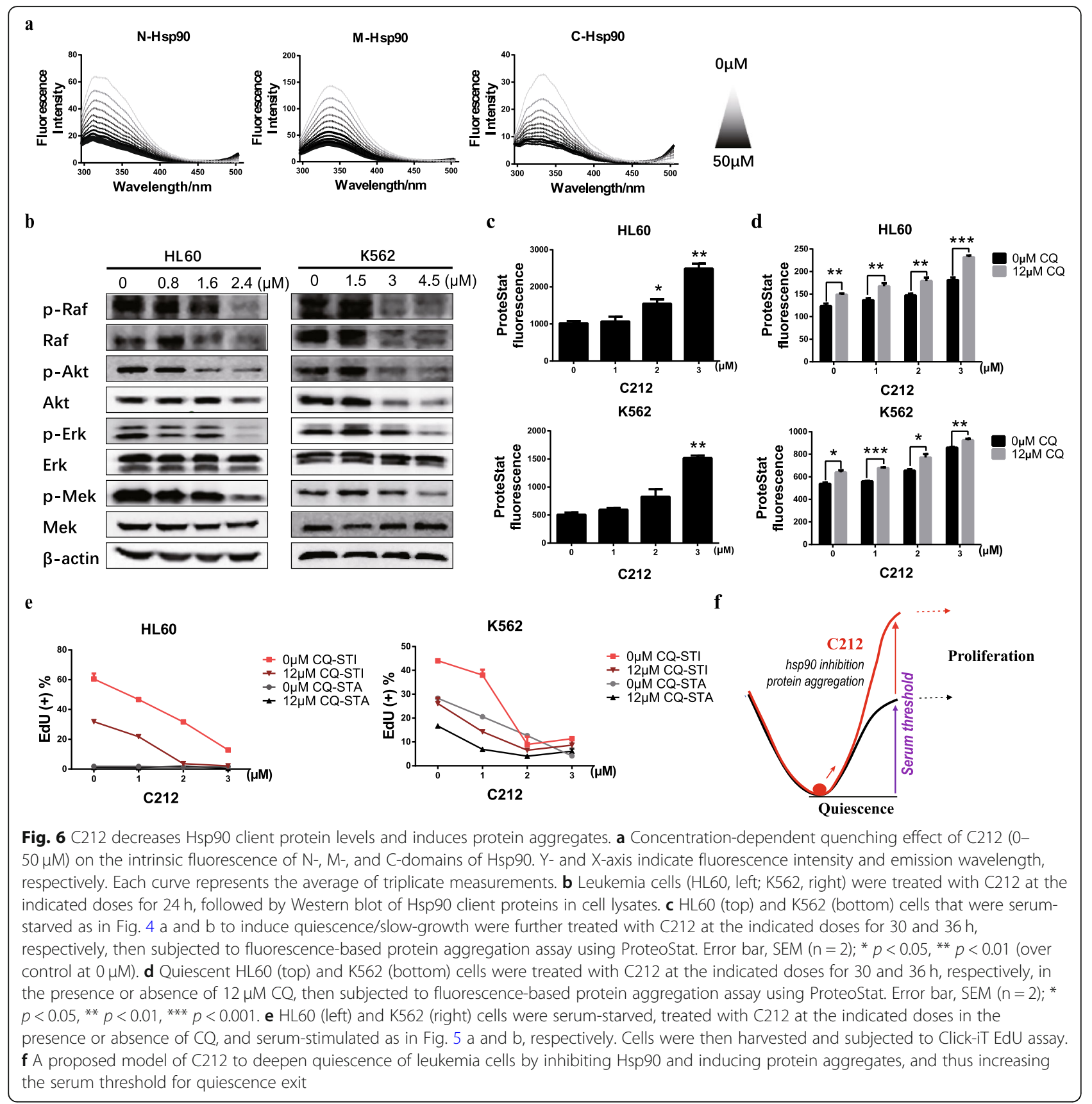

Table 3 Dissociation constant (Kd) values of C212 with different Hsp90 domains

\begin{tabular}{llll}
\hline Compound & Fmax & $\mathrm{Kd}(\mu \mathrm{M})$ & $\mathrm{R}^{2}$ \\
\hline N-Hsp90 & $80.8 \pm 1.1$ & $36.3 \pm 1.0$ & 0.999 \\
M-Hsp90 & $195.8 \pm 2.5$ & $38.7 \pm 0.9$ & 0.999 \\
C-Hsp90 & $32.8 \pm 0.9$ & $15.3 \pm 1.2$ & 0.995 \\
\hline
\end{tabular}

A few significant questions are still unanswered and await future research. First, we found different from in leukemia cells, in colon cancer cells C212 eliminated quiescent cells less effectively than growing ones, behaving similar to chemotherapy drugs in this regard (Fig. S4 A-D). This discrepancy again appeared correlated with the ability of $\mathrm{C} 212$ to inhibit Hsp90 and induce client protein degradation in quiescence. In quiescent leukemia cells HL60 and K562, we found Hsp90 client protein pErk level decreased in a $\mathrm{C} 212$ dose-dependent manner either with (Fig. S3 E and L) or without (Fig. S3 D and 
K) normalizing to Hsp90 level. By contrast, in quiescent colon cancer cells HCT116 and SW620, p-Erk level did not decrease, but increased (although mostly statistically insignificantly) with C212, either with (Fig. S4 I and N) or without (Fig. S4 H and M) normalizing to Hsp90 level. We propose that the ability of C212 to inhibit Hsp90 in quiescence (as in leukemia cells HL60 and K562, but not in colon cancer cells HCT116 and SW620) is a key determinant of whether C212 can effectively eliminate quiescent cells (notion I). On top of this, Hsp70 appeared to also affect the relative sensitivity of quiescent and growing cells to C212. In HL60 and K562 cells (exhibiting C212-induced Hsp90 inhibition and client protein degradation), the increase of Hsp70 level was noticeably higher in growing $\mathrm{K} 562$ cells compared to the other three cell populations (quiescent K562 cells as well as growing and quiescent HL60 cells; Fig. S3 J and C), which was consistent with the apparently higher C212-resistance of growing $\mathrm{K} 562$ cells than the other three cell populations (Fig. 4c and d) considering the role of Hsp70 in repressing apoptosis $[55,56]$. In colon cancer cells HCT116 and SW620 (not exhibiting C212-induced Hsp90 inhibition and client protein degradation, Fig. S4 H-N), Hsp70 level increased with C212 in growing condition but remained undetectable in quiescence (Fig. S4 E and G, HCT116; Fig. S4 J and L, SW620) - still, quiescent colon cancer cells were more resistant to $\mathrm{C} 212$ than growing ones (Fig. S4 C and D). These results suggested that when quiescent cells did not exhibit C212-induced Hsp90 inhibition and client degradation, they were more resistant to C212 killing than their growing counterparts, even without the antiapoptosis protection from $\mathrm{Hsp} 70$ as growing cells had (notion II). These two related notions (I and II) need to be studied more extensively and with other cell types in future research, as well as the potential reasons underlying the seemingly cell-type specific effects of C212 (e.g., whether due to differences in intracellular drug availability, suspension vs. adherent environment, or other confounding factors).

Second, we note that inhibiting Hsp90 did not solely account for the action of C212. When we targeted to inhibit Hsp90 using 17-AAG, a classic Hsp90 inhibitor, we found in both HL60 and K562 leukemia cells, growing cells instead of quiescent ones were preferentially eliminated (Fig. S5 A and B). Yet, comparable trends were observed regarding $\mathrm{Hsp} 90$ and client protein (p-Erk) level changes in response to 17-AAG and C212 in these cells (Fig. S5 C and J). Particularly, Hsp90 level increased slightly (but mostly statistically insignificantly; Fig. S5 DF, HL60; Fig. S5, K-M, K562), and p-Erk level decreased significantly (Fig. S5 G-I, HL60; Fig. S5, N-P, K562), with increasing doses of C212, 17-AAG, and their combinations. These results suggested that the action of C212 involved cellular targets beyond Hsp90 alone, a notion consistent with the broad spectrum of molecular targets known to curcumin and its derivatives [20,21]. For example, C212 may target cell survival factors not associated with Hsp90, or it may directly target some Hsp90 client proteins independent of Hsp90 inhibition (as curcumin does [21, 57]). The exact underlying mechanism(s) await future studies.

\section{Conclusion}

Here, we report that C212, a 4-arylmethyl curcumin derivative, exhibits a dual effect in eliminating both growing and quiescent leukemia cells. C212 inhibits growing leukemia cells at a higher efficacy than curcumin by inducing apoptosis and G2/M accumulation; it also kills quiescent leukemia cells in deep dormancy that are resistant to conventional chemotherapy drugs. The cytotoxicity of $\mathrm{C} 212$ against leukemia cells is related to its inhibition of Hsp90, leading to client protein degradation and protein aggregation. We expect that further elucidating the molecular mechanisms underlying the dual effect of C212, particularly its preferential elimination of quiescent leukemia cells, may lead to novel therapeutic strategies in treating leukemia and preventing its recurrence from residual dormant cancer cells.

\section{Supplementary information}

Supplementary information accompanies this paper at https://doi.org/10. 1186/s12964-020-00652-4.

Additional file 1 : Fig. S1. C212 induces G2/M cell accumulation. (A) Chemical structures of curcumin and C212. ( $B$ and C) Growing leukemia cells were treated with C212 at the indicated doses for $24 \mathrm{~h}$ and subjected to cell-cycle analysis with PI staining of DNA content $(B, \mathrm{~K} 562$; $C, \mathrm{HL} 60$ ). Error bar, SEM $(n=2){ }^{*} p<0.05, * * p<0.01$ (over control at $0 \mu \mathrm{M})$. (D) Cells were treated with C212 as in $B$ and $C$ and subjected to Western blot of Cdc2 and cyclin B1 proteins (left, K562; right, HL60). Fig. S2. C212 binds to Hsp90 and induces proteasome-dependent client protein degradation. (A) Molecular docking simulation of the binding of curcumin, C212, and 17-AAG to Hsp90 at its C-terminus, middle (M-)region, and N-terminus. (B) Growing HL60 cells were pretreated with or without C212 $(2.4 \mu \mathrm{M})$ for $2 \mathrm{~h}$, followed by co-treatment with or without MG132 $(1 \mu \mathrm{M})$ for $12 \mathrm{~h}$; whole-cell lysate was then subjected to Western blot. Fig. S3 Growing and serum starvation-induced quiescent HL60 (A) and K562 $(H)$ cells were treated with C212 at the indicated doses for $24 \mathrm{~h}$, followed by Western bolt assay. Protein levels of Hsp90 (B, HL60; I, K562), Hsp70 (C, HL60; J, K562), and Hsp90 client protein p-Erk (D, HL60; K, K562) were normalized to $\beta$-actin loading control and plotted against C212 doses. Also shown are p-Erk levels normalized to corresponding Hsp90 levels at tested C212 doses ( $E, H L 60 ; L, K 562)$. Insets in D-L show the enlarged bar graphs corresponding to Quiescence. Error bar, SEM $(n=2)$; * $p<0.05,{ }^{* *} p<0.01,{ }^{* * *} p<0.001$ (over control at $0 \mu \mathrm{M}$ ). Fig. S4 HCT116 (A) and SW620 (B) cells were serum-starved for 12 and $24 \mathrm{~h}$ with EBSS, respectively, to induce quiescence/slow-growth; EdU $(10 \mu \mathrm{M})$ was added to the medium, and cells were further incubated for $24 \mathrm{~h}$, followed by EdU incorporation assay. Growing: control cells not deprived of serum but otherwise under the same treatment. Error bar, SEM $(n=2)$. (C and D) Growing and serum starvation-induced quiescent HCT116 (C) and SW620 (D) cells were treated with C212 at the indicated doses for $48 \mathrm{~h}$ and subjected to MTS assay. Error bar, SEM $(n=3)$. (E-N) Growing and serum starvation-induced quiescent cells (, HCT116; J, SW620) were treated with 
$\mathrm{C} 212$ at the indicated doses for $24 \mathrm{~h}$, followed by Western bolt assay. Protein levels of Hsp90 (F, HCT116; K, SW620), Hsp70 (G, HCT116; L, SW620), and Hsp90 client protein p-Erk (H, HCT116; M, SW620) were normalized to $\beta$-actin loading control and plotted against C212 doses. Also shown are $\mathrm{p}$-Erk levels normalized to corresponding $\mathrm{Hsp} 90$ levels at tested C212 doses $\left(1\right.$, HCT116; N, SW620). Error bar, SEM $(n=2) ;{ }^{*} p<0.05$, ** $p<0.01$, *** $p<0.001$ (over control at $0 \mu \mathrm{M}$ ). Fig. S5. The effects of 17-AAG versus C212 on leukemia cells. Growing and serum starvation-induced quiescent (as in Fig. $4 \mathrm{a}$ and b) HL60 (A) and K562 (B) cells were treated with 17AAG at the indicated doses for $48 \mathrm{~h}$, followed by MTS assay. Error bar, SEM $(n=3)$. Growing HL60 (C- $)$ and K562 (J-P) cells were treated with C212, 17-AAG, or their combination at the indicated doses for $24 \mathrm{~h}$, followed by Western blot assay. Protein levels of Hsp90 (D-F, HL60; K-M, K562) and client protein p-Erk (G-1, HL60; N-P, K562) were normalized to $\beta$-actin loading control and plotted against the treatment doses of $\mathrm{C} 212$, $17-\mathrm{AAG}$, or their combination. Error bar, SEM $(\mathrm{n}=2) ;{ }^{*} p<0.05,{ }^{* *} p<$ $0.01,{ }^{* * *} p<0.001$ (over control at $0 \mu \mathrm{M}$ ).

\section{Abbreviations}

Hsp90: Heat shock protein 90; MMP: Mitochondrial membrane potential; PARP: Poly (ADP-ribose) polymerase; Cdc2: Cyclin dependent kinase 1; IC50: The concentration required to inhibit cell growth/viability by $50 \%$

\section{Acknowledgments}

We thank the Foundation for Scholarly Exchange of Fujian Medical University for sponsoring B.L. and the University of Arizona Cancer Center for providing leukemia cells and flow cytometry facilities.

\section{Authors' contributions}

B.L., Y.S., Y.L., J.X. and G.Y. designed research; B.L., Y.S., H.H., Y.F., M.W., K.D.C performed experiments; B.L., Y.S., J.X. and G.Y. analyzed data; and B.L., J.X. and G.Y. wrote the paper. All authors read and approved the final manuscript.

\section{Funding}

This work was supported by grants from National Science Foundation (DMS1463137, to G.Y.) and the University of Arizona (RDI-Accelerate for Success, to G.Y.); and grants from the National Natural Science Foundation of China (81973364, to J.X.), the Joint Funds for the Innovation of Science and Technology, Fujian Province, China (2016Y9059, to J.X.), the Project of Fujian Natural Science Foundation (2016 J01050, to Y.L.), the Medical Innovation Project of Fujian Provincial Health Commission (2016-CX-42, to Y.L.), and the Startup Fund for scientific research, Fujian Medical University (2017XQ2016, to B.L.).

\section{Availability of data and materials}

All the data generated or analyzed for this project are included either in this article or in the supplementary information files.

\section{Ethics approval and consent to participate}

Not applicable.

\section{Consent for publication}

All authors read and are consent for the publication of the manuscript.

\section{Competing interests}

The authors declare no competing interest.

\section{Author details}

${ }^{1}$ School of Pharmacy, Fujian Provincial Key Laboratory of Natural Medicine Pharmacology, Fujian Medical University, Fuzhou 350122, China.

${ }^{2}$ Department of Molecular and Cellular Biology, University of Arizona, Tucson, AZ 85721, USA. ${ }^{3}$ The Second Affiliated Hospital of Fujian Medical University, Quanzhou 362000, Fujian, China. ${ }^{4}$ Arizona Cancer Center, University of Arizona, Tucson, AZ 85719, USA.
Received: 31 January 2020 Accepted: 26 August 2020

Published online: 29 September 2020

\section{References}

1. Lüpertz R, Wätjen W, Kahl R, Chovolou Y. Dose- and time-dependent effects of doxorubicin on cytotoxicity, cell cycle and apoptotic cell death in human colon cancer cells. Toxicology. 2010;271:115-21.

2. Liu K, Cang S, Ma Y, Chiao JW. Synergistic effect of paclitaxel and epigenetic agent phenethyl isothiocyanate on growth inhibition, cell cycle arrest and apoptosis in breast cancer cells. Cancer Cell Int. 2013;13:10.

3. Zhang F-L, Wang P, Liu Y-H, Liu L-B, Liu X-B, Li Z, Xue Y-X. Topoisomerase I inhibitors, shikonin and topotecan, inhibit growth and induce apoptosis of glioma cells and glioma stem cells. PLoS One. 2013;8:e81815.

4. De Angelis ML, Francescangeli F, La Torre F, Zeuner A. Stem cell plasticity and dormancy in the development of Cancer therapy resistance. Front Oncol. 2019;9:626.

5. Blagosklonny MV. Target for cancer therapy: proliferating cells or stem cells. Leukemia. 2006;20:385-91.

6. Senft D, Jeremias I. Tumor cell dormancy-triggered by the niche. Dev Cell. 2019;49:311-2.

7. Aguirre-Ghiso JA, Sosa MS. Emerging topics on disseminated Cancer cell dormancy and the paradigm of metastasis. Ann Rev Cancer Biol. 2018;2: 377-93

8. Summers MA, McDonald MM, Croucher PI. Cancer Cell Dormancy in Metastasis. Cold Spring Harb Perspect Med. 2020;10:a037556.

9. Essers MA, Trumpp A. Targeting leukemic stem cells by breaking their dormancy. Mol Oncol. 2010;4:443-50.

10. Rossari F, Zucchinetti C, Buda G, Orciuolo E. Tumor dormancy as an alternative step in the development of chemoresistance and metastasis clinical implications. Cell Oncol. 2020;43:155-176.

11. Lemons JM, Feng XJ, Bennett BD, Legesse-Miller A, Johnson EL, Raitman I, Pollina EA, Rabitz HA, Rabinowitz JD, Coller HA. Quiescent fibroblasts exhibit high metabolic activity. PLoS Biol. 2010;8:e1000514.

12. Roesch A, Vultur A, Bogeski I, Wang H, Zimmermann KM, Speicher D, Korbel C, Laschke MW, Gimotty PA, Philipp SE, et al. Overcoming intrinsic multidrug resistance in melanoma by blocking the mitochondrial respiratory chain of slow-cycling JARID1B(high) cells. Cancer Cell. 2013;23: $811-25$.

13. Sharma SV, Lee DY, Li B, Quinlan MP, Takahashi F, Maheswaran S, McDermott U, Azizian N, Zou L, Fischbach MA, et al. A chromatin-mediated reversible drug-tolerant state in cancer cell subpopulations. Cell. 2010;141: 69-80.

14. Viale A, Pettazzoni P, Lyssiotis CA, Ying H, Sanchez N, Marchesini M, Carugo A, Green T, Seth S, Giuliani V, et al. Oncogene ablation-resistant pancreatic cancer cells depend on mitochondrial function. Nature. 2014;514:628-32.

15. Dai J MM, Everetts NJ, et al. : Elimination of quiescent slow-cycling cells via reducing quiescence depth by natural compounds purified from Ganoderma lucidum. oncotarget 2017.

16. Fujimaki K, Yao G. Crack the state of silence: tune the depth of cellular quiescence for cancer therapy. Mol Cell Oncol. 2018;5:e1403531.

17. Esatbeyoglu T, Huebbe P, Ernst IM, Chin D, Wagner AE, Rimbach G. Curcumin-from molecule to biological function. Angew Chem Int Ed. 2012;51:5308-32.

18. Pulido-Moran M, Moreno-Fernandez J, Ramirez-Tortosa C, Ramirez-Tortosa M. Curcumin and health. Molecules. 2016;21:264

19. Anand P, Sundaram C, Jhurani S, Kunnumakkara AB, Aggarwal BB. Curcumin and cancer: an "old-age" disease with an "age-old" solution. Cancer Lett. 2008;267:133-64.

20. Shanmugam MK, Rane G, Kanchi MM, Arfuso F, Chinnathambi A, Zayed ME, Alharbi SA, Tan BK, Kumar AP, Sethi G. The multifaceted role of curcumin in cancer prevention and treatment. Molecules. 2015;20:2728-69.

21. Kunnumakkara $A B$, Anand $P$, Aggarwal BB. Curcumin inhibits proliferation, invasion, angiogenesis and metastasis of different cancers through interaction with multiple cell signaling proteins. Cancer Lett. 2008;269:199225.

22. Sahu A, Kasoju N, Bora U. Fluorescence study of the curcumin- casein micelle complexation and its application as a drug nanocarrier to cancer cells. Biomacromolecules. 2008:9:2905-12.

23. Shinojima N, Yokoyama T, Kondo Y, Kondo S. Roles of the Akt/mTOR/ p70S6K and ERK1/2 signaling pathways in Curcumin-induced autophagy. Autophagy. 2014;3:635-7. 
24. Wilken R, Veena MS, Wang MB, Srivatsan ES. Curcumin: a review of anticancer properties and therapeutic activity in head and neck squamous cell carcinoma. Mol Cancer. 2011;10:12.

25. Giommarelli C, Zuco V, Favini E, Pisano C, Dal Piaz F, De Tommasi N, Zunino F. The enhancement of antiproliferative and proapoptotic activity of HDAC inhibitors by curcumin is mediated by Hsp90 inhibition. Cell Mol Life Sci. 2010;67:995-1004.

26. Lv Y, Gong L, Wang Z, Han F, Liu H, Lu X, Liu L. Curcumin inhibits human cytomegalovirus by downregulating heat shock protein 90. Mol Med Rep. 2015;12:4789-93

27. Wu LX, Xu JH, Huang XW, Zhang KZ, Wen CX, Chen YZ. Down-regulation of p210(bcr/abl) by curcumin involves disrupting molecular chaperone functions of Hsp90. Acta Pharmacol Sin. 2006;27:694-9.

28. Trepel J, Mollapour M, Giaccone G, Neckers L. Targeting the dynamic HSP90 complex in cancer. Nat Rev Cancer. 2010;10:537-49.

29. Takayama S, Reed JC, Homma S. Heat-shock proteins as regulators of apoptosis. Oncogene. 2003;22:9041-7.

30. Taipale M, Krykbaeva I, Koeva M, Kayatekin C, Westover KD, Karras Gl, Lindquist S. Quantitative analysis of HSP90-client interactions reveals principles of substrate recognition. Cell. 2012;150:987-1001.

31. Zhang T, Hamza A, Cao X, Wang B, Yu S, Zhan CG, Sun D. A novel Hsp90 inhibitor to disrupt Hsp90/Cdc37 complex against pancreatic cancer cells. Mol Cancer Ther. 2008;7:162-70.

32. Butler LM, Ferraldeschi R, Armstrong HK, Centenera MM, Workman P. Maximizing the therapeutic potential of HSP90 inhibitors. Mol Cancer Res. 2015;13:1445-51.

33. Solit DB, Chiosis G. Development and application of Hsp90 inhibitors. Drug Discov Today. 2008;13:38-43.

34. Pu Y, Li Y, Jin X, Tian T, Ma Q, Zhao Z, Lin SY, Chen Z, Li B, Yao G, et al. ATPdependent dynamic protein aggregation regulates bacterial dormancy depth critical for antibiotic tolerance. Mol Cell. 2019;73:143-56 e144.

35. Leeman DS, Hebestreit K, Ruetz T, Webb AE, McKay A, Pollina EA, Dulken BW, Zhao X, Yeo RW, Ho TT, et al. Lysosome activation clears aggregates and enhances quiescent neural stem cell activation during aging. Science. 2018;359:1277-83.

36. Chen C, Liu Y, Chen Y, Xu J. C086, a novel analog of curcumin, induces growth inhibition and down-regulation of NFkappaB in colon cancer cells and xenograft tumors. Cancer Biol Ther. 2011;12:797-807.

37. Wu L, Yu J, Chen R, Liu Y, Lou L, Wu Y, Huang L, Fan Y, Gao P, Huang M, et al. Dual inhibition of Bcr-Abl and Hsp90 by $\mathrm{C} 086$ potently inhibits the proliferation of imatinib-resistant CML cells. Clin Cancer Res. 2015;21:833-43.

38. Fan YJ, Zhou YX, Zhang LR, Lin QF, Gao PZ, Cai F, Zhu LP, Liu B, Xu JH. C1206, a novel curcumin derivative, potently inhibits Hsp90 and human chronic myeloid leukemia cells in vitro. Acta Pharmacol Sin. 2018;39:649-58.

39. Yang Liu MY, Wu Q, Wu L, Xu J. Synthesis and evaluation of 4-arylmethyl Curcumin Analgues as potent Hsp90 inhibitors. Lett Drug Design Discov. 2014;11:993-9.

40. Fan Y, Liu Y, Zhang L, Cai F, Zhu L, Xu J. C0818, a novel curcumin derivative, interacts with Hsp90 and inhibits Hsp90 ATPase activity. Acta Pharm Sin B. 2017;7:91-6.

41. Nagaraju GP, Zhu S, Wen J, Farris AB, Adsay VN, Diaz R, Snyder JP, Mamoru S, El-Rayes BF. Novel synthetic curcumin analogues EF31 and UBS109 are potent DNA hypomethylating agents in pancreatic cancer. Cancer Lett. 2013;341:195-203

42. Selvam C, Jachak SM, Thilagavathi R, Chakraborti AK. Design, synthesis, biological evaluation and molecular docking of curcumin analogues as antioxidant, cyclooxygenase inhibitory and anti-inflammatory agents. Bioorg Med Chem Lett. 2005;15:1793-7.

43. Qudjani E, Iman M, Davood A, Ramandi MF, Shafiee A. Design and synthesis of Curcumin-like Diarylpentanoid analogues as potential anticancer agents. Recent Pat Anticancer Drug Discov. 2016;11:342-51.

44. Chen JJGQ, He XM, Yang SX, Chen C, Zhang LR. Study on a screening model for inhibitor of Hsp90 ATPase activity. J Xiamen Univ. 2010;49:711-6.

45. Kwon JS, Everetts NJ, Wang X, Wang W, Della Croce K, Xing J, Yao G. Controlling depth of cellular quiescence by an Rb-E2F network switch. Cell Rep. 2017;20:3223-35.

46. Ali MM, Roe SM, Vaughan CK, Meyer P, Panaretou B, Piper PW, Prodromou C, Pearl LH. Crystal structure of an Hsp90-nucleotide-p23/Sba1 closed chaperone complex. Nature. 2006;440:1013-7.

47. Starr P. Midostaurin the first targeted therapy to improve survival in AML: potentially practice-changing. Am Health Drug Benefits. 2016;9:1-21.
48. Yao G, Lee TJ, Mori S, Nevins JR, You L. A bistable Rb-E2F switch underlies the restriction point. Nat Cell Biol. 2008;10:476-82.

49. Ebinger S, Ozdemir EZ, Ziegenhain C, Tiedt S, Castro Alves C, Grunert M, Dworzak M, Lutz C, Turati VA, Enver T, et al. Characterization of rare, dormant, and therapy-resistant cells in acute lymphoblastic leukemia. Cancer Cell. 2016;30:849-62.

50. Elrick LJ, Jorgensen HG, Mountford JC, Holyoake TL. Punish the parent not the progeny. Blood. 2005;105:1862-6.

51. Graham SM, Jørgensen HG, Allan E, Pearson C, Alcorn MJ, Richmond L, Holyoake TL. Primitive, quiescent, Philadelphia-positive stem cells from patients with chronic myeloid leukemia are insensitive to STI571 in vitro. Blood. 2002;99:319-25.

52. Talpaz M, Estrov Z, Kantarjian H, Ku S, Foteh A, Kurzrock R. Persistence of dormant leukemic progenitors during interferon-induced remission in chronic myelogenous leukemia. Analysis by polymerase chain reaction of individual colonies. J Clin Invest. 1994;94:1383-9.

53. Li J, Soroka J, Buchner J. The Hsp90 chaperone machinery: conformational dynamics and regulation by co-chaperones. Biochim Biophys Acta. 2012; 1823:624-35.

54. Lanneau D, de Thonel A, Maurel S, Didelot C, Garrido C. Apoptosis versus cell differentiation: role of heat shock proteins HSP90, HSP70 and HSP27. Prion. 2007:1:53-60.

55. Clarke PA, Hostein I, Banerji U, Stefano FD, Maloney A, Walton M, Judson I, Workman P. Gene expression profiling of human colon cancer cells following inhibition of signal transduction by 17-allylamino-17demethoxygeldanamycin, an inhibitor of the hsp90 molecular chaperone. Oncogene. 2000;19:4125-33.

56. Solit DB, Zheng FF, Drobnjak M, Münster PN, Higgins B, Verbel D, Heller G, Tong W, Cordon-Cardo C, Agus DB, et al. 17-Allylamino-17demethoxygeldanamycin induces the degradation of androgen receptor and HER-2/neu and inhibits the growth of prostate cancer xenografts. Clin Cancer Res. 2002;8:986-93.

57. Gupta SC, Prasad S, Kim JH, Patchva S, Webb LJ, Priyadarsini IK, Aggarwal BB. Multitargeting by curcumin as revealed by molecular interaction studies. Nat Prod Rep. 2011;28:1937-55.

\section{Publisher's Note}

Springer Nature remains neutral with regard to jurisdictional claims in published maps and institutional affiliations.
Ready to submit your research? Choose BMC and benefit from:

- fast, convenient online submission

- thorough peer review by experienced researchers in your field

- rapid publication on acceptance

- support for research data, including large and complex data types

- gold Open Access which fosters wider collaboration and increased citations

- maximum visibility for your research: over $100 \mathrm{M}$ website views per year

At BMC, research is always in progress.

Learn more biomedcentral.com/submissions 